Jozef Babecka

\title{
Nursing education for patients with diabetes mellitus type 2
}

\author{
St. Elisabeth College of Health and Social Work, Bratislava, Slovakia
}

jozef.babecka@hotmail.com

\author{
Йозеф Б. \\ Сестринська освіта для паціснтів \\ 3 цукровим діабетом 2-го типу \\ Санкт-Елізабет коледж охорони здоров'я \\ та соціальної роботи, Братислава, Словаччина
}

Йозеф Б.

Сестринская подготовка для пациентов с сахарным диабетом 2-го типа

Санкт-Элизабет колледж здравоохранения

и социальной работы, Братислава, Словакия

\section{Introduction}

Clinical studies have demonstrated that diabetes is a metabolic disease caused by insulin deficiency, where insulindeficiency can lead to the increase of blood glucose. In recent years, the results show that, with the gradual improvement of living standards and the change of diet structure,the occurrence of diabetes is increasing year by year. Chronic hyperglycaemia presents a risk of micro and macrovascular complications with manifestations of specific degenerative organ processes. Disease after years of life leads to irreversible changes affecting individual tissues of the organism [1]. At present, the effect of blood glucose control on the prognosis and complications of patients with diabetes is verysignificant, so it is very important to treat the clinical effectof the treatment and nursing. In the current clinical treatment of diabetes, diabetes health education has become aneffective method of treatment. Diabetes health education is a long-term treatment, where in the course of treatment, it needs the patients to have a more comprehensive understanding of diabetes and actively cooperate with the treatment of diabetes. The authors selected 70 cases of patients with diabetes treated in our hospital from May 2012 to May 2013, and analyzed the effect of health education on diabetes care, and summarized in the study.

\section{Materials and methods}

70 cases of diabetic patients chosen from May2012 to May 2013 were divided into two groups, the control group of 35 patients without diabetes health education and the treatment group of 35 cases of with diabetes health education. The control group of 35 patients are summarized as following: male 21 , female 14, with age range between 51-67 years old (the average age is $59 \pm 1.3$ years old) with diabetic history between $1-18$ years, and the patient's fasting blood sugar level range is 11-22 mmol/L. Meanwhile, the treatment group of 35 cases which included: male 22, female 13, aged 52-66 years old, with averageage of $58 \pm 1.4$ years old, with a diabetic history of 1-21 years and the fasting blood glucose level was 11$22 \mathrm{mmol} / \mathrm{L}$. Upon admission, both the two groups of patients were treated with conventional clinical examination and were diagnosed with diabetes. There were no significant differences in gender, age, medical history, symptoms and so on between the two groups.

Both the groups of patients strictly followed the doctor advice and were subjected to strict testing of renal function, blood lipid levels and blood glucose levels, through "Gansulin" treatment. At the same time, the treatment group received day by day health education to enable them to have the basic knowledge on diabetes, the treatment of diabetes drugs and related diet. The patients in the treatment group were also educated on exercise methods, self-monitoring on the possible complications, methods for effective prevention and treatment. It is important for patients to understand the importance of nondrug treatment and the patients should know that the health education of diabetes mellitus is a long-term treatment method. The control group however received routine clinical treatment and nursing care. The clinical data of all patients were analyzed using SPSS 18.0 software and Microsoft Excel 2016.

\section{Results}

After the implementation of diabetes health education, the treatment of diabetes patients with blood glucose control, diabetes related skills and knowledge levels were significantly improved. Two groups of patients after treatment for one week were accessed to evaluate the effect of treatment. Out of 35 patients in treatment group, 31 patients had their fasting blood glucose returning to normal, which accounts for $94.60 \%$. On other hand, for patients in the control group, 18 patients had their fasting blood glucose returning to normal, accounting for $59.70 \%$. Two groups of patients with treatment effect were compared with statistical significance $(\mathrm{p}<0.05)$. The data is shown in Table. 
Table. Two groups of patients with health education efficacy comparison, cases (\%)

\begin{tabular}{|l|c|c|c|c|}
\hline Group & Cases & Blood glucose control rate & Master related skills & Master relevant knowledge \\
\hline Treatment & 35 & $31(94.6)$ & $33(96.8)$ & $32(59.4)$ \\
\hline Control & 35 & $18(58.6)$ & $17(57.2)$ & $15(53.3)$ \\
\hline
\end{tabular}

\section{Discussion}

Diabetes mellitus is a metabolic disease characterized by high blood glucose, which is caused by defect in insulin secretion or its biological function, or both. The long-term presence of high blood sugar in diabetes will result in avariety of tissues damage, especially in the eyes, kidneys, heart, blood vessels and nerves of chronic damage and dysfunction. In the treatment of diabetes, the health education is the main measure while the other treatment measures are complementary to each other. Prior to the implementation of health education, the knowledge of diabetes mellitus on patients with diabetes is analyzed and evaluated. Then, based on the patients' nursing plan, the patients should adhere to healthy eating habits, exercise and self-care. The implementation of diabetes health diabetes is mainly subjected for patients with drug treatment and patients with poor compliance. Diabetes health education is a non-drug treatment method. The purpose is to control the complications and risk factors by lowering blood glucose. With effective control of blood glucose, the emergence of diabetes complications can be avoided and is conducive for the extension of the patient's life. With the use health education, it was found that the observation group was significantly better than the control group. This is because the patients who receive health education care can have a clear understanding of their own disease and future treatment as well as prognosis, their self-protection awareness and self-care ability is strengthened effectively [2], improving the cure rate. Meanwhile, the control group which received routine nursing only, recovered slowly. Thus, the use of health education in nursing methods, did not only improve patients' active treatment, but also improved the doctor-patient relationship, quality of life of patients and treatment effect. From this study, it can be observed that after the implementation of diabetes health education, the diabetes patients' blood glucose control, diabetes related skills and knowledge levels improved significantly. Two groups of patients after treatment for one week were accessed to evaluate the effect of treatment. Out of 35 patients in treatment group, 31 patients had their fasting blood glucose returning to normal, which accounts for $94.6 \%$. On other hand, for patients in the control group, 18 patients had their fasting blood glucose returning to normal, accounting for $58.6 \%$. Two groups of patients with treatment effect were compared with statistical significance $(\mathrm{p}<0.05)$. Thus, the implementation of effective health education in diabetes care can control the patient's disease effectively, improving the quality of life of patients significantly and it is worth promoting it in clinical medicine.

\section{Exercise therapy}

Health care workers should guide patients with diabetes to carry out a reasonable exercise. An appropriate exercise is conducive to improve the body's immune skills, reduce weight, improve blood lipids and blood glucose disorders and work on it for long-term adherence. Belovicova submits in her contribution of 2018 that in obese type 2 diabetics physical activity leads to improvement glycemic profile. Physical activity it also reduces the incidence of the newborn type 2 diabetes mellitus in complex life intervention in individuals with glucose disorders tolerance [3].

\section{$>$ Psychological nursing}

Diabetes is a lifelong disease. It is difficult for the patients to accept it and there will be fear of depression and other emotions. Nursing staff should pay attention at the specific emotional performance of patients with targeted psychological care and communicate well with patients so that the patients can understand that the disease can be cured and the treatment takes a long time. Patients should stay persevere and confidence, so that patients can cooperate with doctors for treatment actively.

\section{$>$ Diet nursing}

The basic treatment of diabetes is to implement effective diet nursing and it is an effective way to control and prevent diabetes. The appropriate diet therapy is beneficial to reduce weight, improve fat metabolism disorders and hypertension. The appropriate diet should be based on the patient standard weight, the nature of the work, nutritional status and calculation of the total calories. Most patients do not control their diet, which is not conducive to the treatment of disease and recovery. Nursing staff have to strictly monitor the patient's diet, develop a suitable diet plan, and the patient should also avoid smoking, to control the blood sugar. Diet should be in the law of eat less but more of healthy meals, have correct timing and quantitatively healthy, eat more fresh fruits, vegetables and beans and eat more foods rich in protein.

\section{$>$ Drug therapy}

Patients should be aware of the danger associated diabetes treatment drugs. For example, to avoid hypoglycemia one should consume the drug before meal, which is the conducive and effective consume time. Upon discharge, the patient should keep in touch with the doctor. If any abnormal side effect occurred, inform the doctor immediately so that effective counter measures can be taken.

\section{Conclusions}

Health education is a new way to enhance the therapeutic effect on the patients. This method is mainly aimed to acknowledge patients with the treatment environment, methods, effect, prevention and control. Health education through health knowledge and disease knowledge transmission reduces the patient's fear of the disease while strengthening the patient's emotional stability towards the treatment. Health education can also improve the patient's understanding of the disease effectively and ensure that patients play a vital role to improve the treatment effect. 


\title{
References
} $1337-592 X$.

1. Popovicova, M., Semes, M. 2018. Diabetic retinopathy. In: DIAspectrum. 2/2018. ročník VII. with. 14 - 15 . ISSN:

2. Supinova, M., Sichtova, A. 2012. The effect of glycemic control on the development of diabetic retinopathy in persons with type 2 diabetes mellitus. In Nursing. ISSN 1338-6263, 2012, vol. 2, no. 4, p. 125-130.

3. Belovicova, M. 2018. Hepatitis and obesity - a modern "scarecrow" for patients with type 2 diabetes mellitus. Vyd: ZDS. In DIA spectrum. 1337-592X, 2/2018, volume VII. p. 18-19.

Дата надходження рукопису до редакції: 08.10.2019 р.

\begin{abstract}
Objective: to study and analyze the effect of nursing education in diabetes care. To evaluate the application of health education in diabetes care to provide a reliable reference for future clinical nursing work.

Methods. From May 2012 to May 2013, 70 cases of diabetic patients treated in Central military hospital in Ruzomberok were divided into two groups. The control group of 35 patients was without diabetes health education and another group of 35 patients was provided with diabetes health education. Both the groups of patients were compared and analyzed with blood glucose control, diabetes related skills and knowledge.

Results. Upon the implementation of diabetes health education, it was found that the diabetes patients of blood glucose control, diabetes related skills and knowledge levels were improved significantly. Two groups of patients undergo treatment for one week, where 35 patients in treatment group and 31 patients in the control group. The fasting blood glucose level of the two groups returned to normal, with 58.6\%, difference between the groups. The comparison of two groups of patients through treatment effect had statistical significance ( $<<0.05)$.

Conclusions. The effective health education in diabetes care can effectively control the patient's symptoms, improve the patients' quality of life and it is worth to be extensively applied in clinical medicine.
\end{abstract}

Key words: nursing care, diabetes mellitus, patient, education.

Мета дослідження: вивчити і проаналізувати вплив сестринської освіти в догляді за хворими з цукровим діабетом. Оцінити застосування медичної освіти при догляді за хворими на цукровий діабет для забезпечення надійного ставлення до майбутньої клінічної сестринської праці.

Методи. 3 травня 2012 р. по травень 2013 р. 70 хворих на цукровий діабет, яких було розділено на дві групи, було проліковано у Центральному воєнному госпіталі в Ружомбероку.

Контрольна група з 35 пацієнтів не отримувала догляду спеціалістів з цукрового діабету, а іншу група 335 пацієнтів було забезпечено допомогою персоналу з освітою $з$ цукрового діабету. Обидві групи пацієнтів порівнювали і аналізували 3 контролем глюкози в крові, навичок та знань пов'язаних з цукровим діабетом.

Результати. Після впровадження медичної освіти по діабету, було встановлено, що у пацієнтів з діабетом контроль глюкози в крові, діабет пов'язані навички та рівні знань значно поліпшилися. Дві групи пацієнтів проходили лікування протягом одного тижня, де 35 в групі, що отримувала лікування та 31 пацієнта у контрольній групі. Рівень глюкози в крові пацієнтів двох груп повернувся до нормального 3 різницею між групами 58,6\%. Порівняння двох груп пацієнтів щодо лікувального ефекту мав статистичне значення $(\mathrm{p}<0,05)$.

Висновки. Ефективне навчання 3 допомоги хворим на цукровий діабет може ефективно контролювати симптоми пацієнта, поліпшити якість життя пацієнтів і його варто широко застосовувати в клінічній медицині.

Ключові слова: догляд, цукровий діабет, пацієнт, освіта.

Цель исследования: изучить и проанализировать влияние сестринской подготовки в уходе за больными с сахарным диабетом. Оценить использование медицинской подготовки при уходе за больными сахарным диабетом для обеспечения надежного отношения к будущей клинической сестринской работе.

Методы. С мая 2012 г. по май 2013 г. 70 больных сахарным диабетом, которые были разделены на две группы, было пролечено в Центральном военном госпитале в Ружомбероке. Контрольная группа из 35 пациентов не получала ухода специалистов по сахарному диабету, а вторая группа из 35 пациентов была обеспечена помощью персонала с подготовкой по сахарному диабету. Обе группы пациентов сравнивали и анализировали с контролем глюкозы в крови, навыков и знаний, связанных с сахарным диабетом.

Результаты. После внедрения медицинской подготовки по диабету, было установлено, что у пациентов с диабетом контроль глюкозы в крови, диабет-связанные навыки и уровень знаний значительно улучшились. Две группы пациентов проходили лечение в течение одной недели, с 35 пациентами в группе, получавшей лечение, и 31 пациентом в контрольной группе. Уровень глюкозы в крови пациентов двух групп вернулся к нормальному с разницей между группами 58,6\%. Сравнение двух групп пациентов относительно лечебного эффекта имело статистическое значение $(\mathrm{p}<0,05)$.

Выводы. Эффективное обучение помощи больным с сахарным диабетом может эффективно контролировать симптомы пациента, повысить качество жизни пациентов и его стоит широко применять в клинической медицине.

Ключевые слова: уход, сахарный диабет, пациент, образование.

\section{Відомості про автора}

Jozef Babecka - PhDr., PhD, St. Elisabeth College of Health and Social Work; Nam. 1. maja 1, 810 00, Bratislava, Slovakia. jozef.babecka@hotmail.com. 